\title{
The death of Catholicos Ambrosius and its impact on the fate of the Georgian Orthodox Church in Zygmunt Mostowski's opinion*
}

Outline of content: The article presents a report written in April 1927 by Zygmunt Mostowski, the Polish consul in Tbilisi, on the situation in the Georgian Orthodox Church after the death of Catholicos-Patriarch of All Georgia Ambrosius, and discusses the most important conclusions drawn by the Polish diplomat from the events related to the conflict within the Georgian Orthodox Church resulting from its infiltration by the Soviet special services.

Keywords: Catholicos Ambrosius, Georgia interwar period, Zygmunt Mostowski, Georgian Orthodox Church, Polish diplomacy in II RP

The archives which are part of the Polish Institute and Sikorski Museum in London (20, Prince's Gate, London, SW7 1PT) hold approximately one and a half kilometre of shelves on which various historical documents are stored. Most of them concern the period of World War II and Poland's participation in it. Part of the collected material is related to the activity of Polish diplomatic missions, including the Polish embassy in London in the interwar period. Due to the strategic importance of this post, information from other Polish missions, among others from the Consulate General in Tiflis, was forwarded to it. ${ }^{1}$ Letters received from the Caucasus are stored in the archives in the assembly: Embassy of the Republic of Poland in London, no. A.12P, subassembly no. 11, file no. 3, titled "Soviet Russia - political and information reports from the Consulates in Leningrad, Minsk and Tiflis". Among them there is the report: "On the death of Catholicos Ambrosius and the split in the Georgian Orthodox Church", drawn up by Zygmunt Mostowski. The Polish diplomat was a first-class consul and head of the consulate in Tiflis in the years 1926-1931.

\footnotetext{
* This article was written owing to the support of the De Brzezie Lanckoronski Foundation.

${ }^{1}$ In 1936, the name of the city was changed to Tbilisi.
} 
By signing the Peace Treaty of Riga in 1921, which ended the war with Soviet Russia, the Polish delegation did not agree to extend its provisions to cover Transcaucasia. In this way, Poland did not recognize the Bolshevik conquest of the area, but at the same time the Poles living there were not covered by the repatriation terms provided for in the agreement. ${ }^{2}$ Its provisions were officially extended to cover Transcaucasia in 1923 when Poland recognized the establishment of the Union of Soviet Socialist Republics. In turn, consular affairs were regulated in detail by the Polish-Soviet consular convention signed in 1924, where the entire territory of the USSR was treated as a single organism. According to its provisions, Poland was entitled to open consulates in Leningrad, Khabarovsk and Kiev, while the Soviet Union in Łódź and Lviv. In addition, in the case of opening a Soviet general consulate in Gdańsk, the Polish side could open a similar post in Tiflis. This happened two years after the signing of the convention, i.e. in 1926. The main task for the employees of the Polish consulate was to take care of the local Poles living in the South Caucasus who, according to the 1926 census results, numbered 6,324. ${ }^{3}$ Another important task was to maintain appropriate relations with the authorities of the Transcaucasian Socialist Federative Soviet Republic and to collect political and economic information about it. This was a consequence of such an arrangement by the Polish authorities of the network of diplomatic missions in the USSR, that they would possibly form complementary information points on the eastern neighbour. ${ }^{4}$ For this reason, the staff of the mission in Tiflis drew up memos which were important from the Polish point of view, especially on matters relating to the stability of the Bolshevik power in the Soviet Union, and the attitude of various social groups to it. They were in fact matters which remained in the centre of interest of political decision-makers from Warsaw.

It is from the above perspective that the causes for the drawing up of the document "On the death of Catholicos Ambrosius and the split in the Georgian Orthodox Church" of April 1927 should be considered (the day of the month was not specified). The report was sent in duplicate to the Ministry of Foreign Affairs in Warsaw, and the diplomatic missions in $\mathrm{Moscow}^{5}$ and in London received one copy each. ${ }^{6}$ It reached the latter on 23 May and was marked as "top secret".

The document begins with a description of Ambrosius' merits ${ }^{7}$ related to

2 W. Materski, Gruzja, Warszawa, 2000, p. 287.

${ }^{3}$ Всесоюзная перепись населения 1926 года, http://demoscope.ru/weekly/ssp/ussr_nac_26. php?reg=5 (access: 06 January 2016).

${ }^{4}$ W. Materski, "Polsko-radziecka konwencja konsularna z 18 lipca 1924 roku", Dzieje Najnowsze, 4 (1973), pp. 65-66.

5 The Polish diplomatic mission in Moscow was elevated to the rank of embassy in 1934.

${ }^{6}$ Until 1929, Poland was represented in Great Britain by a diplomat with the rank of minister, and then by one with the rank of ambassador.

7 Ambrosius, actually Vissarion Khelaia (1861-1927), was well-known, among others, for his efforts to restore the autocephaly of the Georgian Orthodox Church, and for his negative attitude to the Bolsheviks. 
his struggle to preserve the independence of the Georgian Orthodox Church. Mostowski wrote that "the well-known defender of independence of the Georgian Orthodox Church, Catholicos-Patriarch of All Georgia Ambrosius, died in Tiflis on 26 March" ${ }^{8}$ According to his words, the deceased was a patriot, a man of great intellectual advantages and good heart. He repeatedly manifested his honesty in the times of severe distress experienced by his homeland. The Polish diplomat stressed that the testimony of the civic courage and integrity of Ambrosius' character was revealed even in the fact that he asked the participants in the Genoa Conference ${ }^{9}$ to protest against the Soviet aggression in 1921, or that he constantly opposed, with his characteristic resolve, the unlawful acts and atrocities committed by the new Soviet authorities, the looting of Church property, etc.

Later in the report, the diplomat stressed that Ambrosius enjoyed great popularity, which had to be reckoned with even by his enemies. However, due to his bold statements and not subduing to the authorities, the Catholicos was for several months held under house arrest and was then imprisoned by the Cheka (All-Russian Emergency Commission for Combating Counter-Revolution and Sabotage $)^{10}$ along with several members of the Patriarchal Council. Mostowski mentioned in this context Bishop Tsintsadze, ${ }^{11}$ Bishop Paul ${ }^{12}$ and Fr. Mirianashvili. ${ }^{13}$ The Pole also noted that along with arresting the church dignitaries, the Soviet authorities decided to close and seal many Georgian churches. ${ }^{14}$ In the report Mostowski informed that, in accordance with the decision of the People's Court, all of the named priests were sentenced to long imprisonment. However, already

8 The date of Ambrosius's death provided by Z. Mostowski differs from the official date of the death of the Catholicos, i.e. 29 March 1927.

${ }^{9}$ It is about the memorandum that Ambrosius sent to the participants in the Genoa Conference on 7 February 1922. He described the conditions in Georgia after taking hold of its territory by the Red Army. In addition, in the document he expressed a protest on behalf of the Georgian people against the Soviet occupation. The Catholicos called the civilized world to respond to the aggressive policy of the Bolshevik regime; cf. L. Tchantouridze, "Russian Annexes Georgia. Georgian Patriarch's Letter to the 1922 Genoa Conference", Canadian Journal of Orthodox Christianity, 3 (2008), no. 3, pp. 67-73.

10 Catholicos Ambrosius and members of the Council were arrested in February 1923. On 10 March 1924, a trial of priests accused of counter-revolutionary crimes, most of which consisted in hiding the assets of the Orthodox Church from confiscation, began in Tiflis. During the trial, accusations related to, among others, the Catholicos' appeal to the participants in the Genoa Conference to help defend Georgia against Bolshevik troops, were added. On 19 March, the court sentenced Catholicos Ambrosius, for "the preparation of false rumours, hiding valuables and resisting authority", to nine years in prison and confiscation of property; cf. Святой исповедник Амвросий (Хелая) перед коммунистическим правосудием. Сборник составила, предисловием и комментариями снабдила Динара Дарсалия, Тбилиси (n.d.).

11 It is about Kalistrate Tsintsadze, who, in 1932, was elected Catholicos.

${ }^{12}$ It is about Paul Japaridze, who in the years $1924-1930$ was the bishop of Tsilkani. At the time of his arrest by the Cheka, he was an archimandrite.

${ }^{13}$ In his report, Z. Mostowski slightly distorted the name and wrote it in the form of: Marjonishvili.

${ }^{14}$ According to estimates, in the years 1922-1923 approx. 1,200 churches were closed in Georgia. 
in 1924, following the suppression of the uprising in Georgia, ${ }^{15}$ the USSR Central Executive Committee, in a session held in Tiflis, decided to release the imprisoned members of the clergy, ${ }^{16}$ allowed them to return to their bishoprics and assume the previously held positions, and ordered to reopen the closed churches. According to the diplomat, the amnesty was granted because the communists realised that the persecution of Catholicos Ambrosius, and the clergy loyal to him, provoked hostility to the Soviet power among both the Georgian intelligentsia and workers.

According to the report of the Polish diplomat, the Bolsheviks were unable to reduce the influence of Catholicos Ambrosius, who had enormous moral authority, nor did they manage to achieve their objectives in both religious and denominational matters, or in internal policy. As a result, the Soviet government in Moscow launched a very insidious and perfidious campaign aimed at the liquidation of independence and subordination of the Georgian Orthodox Church to the central authorities of the state. The Bolsheviks chose this course of action to formally leave Catholicos Ambrosius in his position, but at the same time to deprive him of real power using constant intrigue, persecution, and inciting discord among the priests loyal to him. In this way, they tried to lead to a split among the clergy and so to destroy the unity of the Georgian Orthodox Church, in order to ultimately eliminate its autocephaly. ${ }^{17}$ According to Mostowski, using these methods the communists wanted to restore the situation that had prevailed at the beginning of the $19^{\text {th }}$ century following the annexation of Georgia to Russia. At that time, one of the most important decisions taken in the first few years by the Russian authorities was to eliminate the autocephaly of the Georgian Orthodox Church and to subordinate it to the Russian Synod. ${ }^{18}$ Additionally, this was not done in the canonical way, but by using violence. From that time until the fall of tsarism, not only the Georgian Orthodox Church, but all Orthodox churches in Georgia were subordinated to the exarch designated by the Synod.

The diplomat noted in the report that the situation changed immediately after the beginning of the Russian Revolution. ${ }^{19}$ It was then that Georgian bishops restored the autocephaly of the Georgian Orthodox Church at the congress which

15 An anti-communist uprising in Georgia took place at the turn of August and September 1924, beginning on 28 August. On that day, a temporary Georgian government headed by Giorgi Tsereteli was formed. By 5 September, the uprising was suppressed and approx. 3,000 people had been killed by then, followed by the shooting of approx. 12,000; А. Топтыгин, Неизвестныци Берия, Москва, 2002, p. 18.

16 The priests were released from prison in March 1925.

${ }_{17}$ In the Soviet period, the autocephaly of the Georgian Orthodox Church was maintained.

18 The Georgian Orthodox Church obtained its autocephaly in the middle of the 5th century, becoming independent from Antioch. In 1801, Georgia (the Kingdom of Kartli and Kakheti) became part of the Russian Empire, and on 21 June 1811 the Holy Synod ousted Catholicos Anton II from power and abolished the office. From that time until March 1917, the Orthodox Church in Georgia had the status of the Georgian Exarchate of the Russian Orthodox Church. The first exarch was the metropolitan Varlaam (Eristavi).

19 I.e. the February Revolution of 1917. 
was held in March 1917. ${ }^{20}$ During its subsequent sessions, which took place in August of the same year, a new status of the autocephaly of the Church was developed and at the same time Bishop Kirion was elected Catholicos. However, he died in the summer of $1918,{ }^{21}$ shortly after his election. The metropolitan of Tiflis, Leonid, was elected the new superior of the Orthodox Church. ${ }^{22} \mathrm{He}$ was solemnly proclaimed Catholicos on 23 February 1919 at the Council of Mtskheta, the former capital of the Georgian state, which until today remains the religious centre of Georgia. ${ }^{23}$ After Leonid's death, ${ }^{24}$ Ambrosius became the third Catholicos, ${ }^{25}$ to whom fell the martyr's role of defending the independence of the Georgian Orthodox Church against the greedy designs of central Soviet authorities.

In his report, Zygmunt Mostowski pointed out that the last years of Ambrosius' life were a period of suffering caused by physical weakness, long stay in prison, as well as tiresome moral harassment and intrigues. This prompted the cleric's death, awaited by his sworn enemies from the Bolshevik camp. The Polish diplomat pointed out that in his recent years the venerable Catholicos ${ }^{26}$ was almost entirely passive, which resulted from his physical weakness and neuro-psychological exhaustion caused by the paralysis of all his activities by the Bolsheviks. The author of the report pointed out that, despite everything, the Catholicos enjoyed great popularity and the whole society regarded him as the rock guarding the independence of the national Orthodox Church, whose members accounted for $90 \%$ of the country's population. ${ }^{27}$

${ }^{20}$ On 12 March (25 March according to the old style), at the Council of Mtskheta, representatives of the Georgian Orthodox Church restored its autocephaly. In the same month, the interim government under the leadership of Georgy Lvov recognized the autocephaly. However, the Russian Orthodox Church did not do it, in view of which relations between the two Orthodox churches were broken off and remained such until 1943 when the Moscow Patriarchate recognized the autocephaly of the Georgian Orthodox Church.

${ }^{21}$ Kyrion II (Giorgi Sadzaglishvili) was elected Catholicos at the council which took place in September 1917 in Tiflis. His enthronement took place on 1 October in Mtskheta. Kyrion II did not die a natural death but was murdered at the end of June 1918 in his residence in Martkopi, to the east of Tiflis; cf. V. Kiknadze, "Krótki zarys życia i działalności katolikosa-patriarchy Kiriona II", in: Dokumenty klasztoru oo. kamedułów z Pożajska w Państwowym Archiwum Historycznym $w$ Tbilisi, ed. I. Czamańska, Poznań, 2012.

${ }^{22}$ Leonid was elected to succeed the murdered Kyrion II on 29 November 1918.

23 According to a legend, Mtskheta was founded in the $2^{\text {nd }}$ half of the $1^{\text {st }}$ millennium BC by Mtskhetos. In the $4^{\text {th }}$ century BC, Parnawaz, the king of Kartli, chose it as his residence. Mtskheta lost the status of the capital of the kingdom of Kartli at the end of the $5^{\text {th }}$ century AD to Tbilisi. Since the $5^{\text {th }}$ century Mtskheta was the religious capital of Georgia, where Catholicos' cathedral - Svetitskhoveli - was located.

${ }^{24}$ Leonid died on 11 June 1921 during an epidemic of cholera.

25 Ambrosius was elected Catholicos on 7 September 1921 and his enthronement took place on 14 October.

26 At the time of his death, Ambrosius was 66.

${ }^{27}$ In this case, Z. Mostowski provides overstated data. According to the census conducted in 1926, Georgia was inhabited by approx. 2,650,000 people, of whom $67 \%$ were Georgians constituting the largest and main group of the faithful of the Georgian Orthodox Church. Even if we added 
According to Mostowski, despite the significant incapacitation of the superior of the Orthodox Church, the communists were unable to fully implement their destructive plans in the environment nearest and loyal to the Catholicos. For this reason, they organized in Kutaisi ${ }^{28}$ a meeting of several bishops who had been successfully drawn by the new government into the orbit of its influence. The communists eventually brought about the situation in which they elected a new council for the Catholicos and a new vice-Catholicos - Bishop Christophor Tsitskishvili, ${ }^{29}$ who was to become an obedient tool in the hands of the Bolsheviks. The previous vice-Catholicos, Kalistrate Tsintsadze, ${ }^{30}$ had been intimidated and forced to resign. It was at that time that the GRU ${ }^{31}$ closed and sealed the office of the Catholicos' council loyal to Ambrosius. Next, following the meeting in Kutaisi and the election of the council made up of supporters of the Soviet power, it was released for their disposal. In this situation, facing such apparent violation of Catholicos Ambrosius' rights, oblivious to his plight, he gathered together, at his place, all the bishops for a confidential meeting. In this way, he attempted to prevent a split in the so far united, according to Mostowski, Georgian clergy which successfully resisted the deliberate intrigues directed against the independence of the Georgian Orthodox Church.

The direct source (the Polish consul did not make it clear who he or she was) informed the diplomat that, at the confidential meeting organized by Ambrosius, there was a heated debate concerning the recognition of the new vice-Catholicos, Tsitskishvili. These discussions, however, did not lead to adopting a common position. Besides, five bishops who were deeply hurt by the fact that some of the participants in the meeting yielded to the influences and intrigues of the communists ostentatiously left the meeting. In addition, three of them, the consul informed, considered converting to Catholicism. These events deeply affected a large part of the Georgian intelligentsia, among whom the bishops' intent regarding the change

to it the Ossetians (4\% of the republic's population), Russians (3\%) and Abkhazians (2\%), the population of Georgia consisted in approx. $76 \%$ of the nations and ethnic groups that traditionally professed Orthodoxy. However, we should also subtract from this result the fast growing group of atheists; cf. Всесоюзная перепись населения 1926 года, http://demoscope.ru/weekly/ ssp/ussr_nac_26.php?reg=5 (access: 29 August 2016).

28 Since 1936, the city has been called Kutaisi.

29 In March 1922, Christophor Tsitskishvili became the bishop of Urbnisi. During the period of Catholicos Ambrosius's being under arrest, i.e. from February 1923 until March 1925, he was the leader of the Provisional Board of the Orthodox Church. In April 1925, Ch. Tsitskishvili was conferred the rank of metropolitan and was transferred to the bishopric of Abkhazia. After Ambrosius' death, Tsitskishvili was elected Catholicos (Christophor III) and he held the office until 1932.

${ }^{30}$ Kalistrate Tsintsadze was one of those council members who were arrested together with Catholicos Ambrosius in 1923. Following the death of Christophor III in 1932, Tsintsadze was elected Catholicos (Kalistrate).He retained this title until his death in 1952.

31 The official name was: State Political Board of the People's Commissariat of Internal Affairs of the Russian Federative Soviet Socialist Republic. It was the political police. 
of denomination gained much popularity and support. As Mostowski wrote in his report, his reliable source assured that a mass conversion of the Georgian intelligentsia to Catholicism could surely be expected. This would be a protest against the penetration of the Georgian Orthodox Church with communist influence. It seemed possible and probable to the diplomat because, as he reported, the tendency among the Georgian intelligentsia to convert to Catholicism was confirmed by the previous years' statistics, showing a fairly significant increase in the number of Georgians-Catholics. As an example, the consul cited the data according to which every year, only in Tiflis itself, 20 people from the Georgian intelligentsia converted to Catholicism. According to Z. Mostowski, it was a very large number by local standards, especially if we take into account the small number of the intelligentsia in relation to the other social classes.

The author of the report was convinced that even if the split in the Georgian Orthodox Church and the potential conversion to Catholicism of three bishops did not entail the conversion to Catholicism of almost the whole Georgian intelligentsia, as his source informed, it would certainly encourage many individuals from the circles in opposition to the communists to take such a step. The diplomat also stressed that there was no doubt that these important events within the Georgian Orthodox Church and the death of Catholicos Ambrosius would greatly facilitate the dangerous tasks undertaken by destructive elements. He also noted that the Georgian Orthodox Church was in a difficult period of upheaval.

Mostowski was of the opinion that the most important issue that the Georgian Orthodox Church was facing was the election of the new Catholicos. A council convened to this end was to be held in June. ${ }^{32}$ At the same time, the consul was convinced that the central organs of the federal government, Communist Party activists and the Russian Orthodox clergy remaining under their influence, would make every effort to achieve their objectives after the death of Catholicos Ambrosius. For it was him who, having strong moral authority and enjoying enormous popularity, maintained solidarity in the circles of the Georgian clergy, and successfully defended, for a long time, the independence of the Georgian Orthodox Church.

The consul pointed out that in tsarist times the Orthodox Church in Georgia, Georgian and Russian alike, was subordinated to the Synod, which appointed from among its members an exarch administering the Orthodox Church in its ongoing activity. ${ }^{33}$ Following the announcement of Georgia's independence and the restoration of the autocephaly of the Church of Georgia, only the Georgians submitted to the Catholicos of Georgia. The Russians did not recognize his authority over them

32 The council was held on 21 June.

33 An exarch is the head of an exarchate, i.e. an Orthodox Church administrative unit, which dates back to the Byzantine period. Currently, exarchates are usually called districts outside the territory of the main activity of a given Orthodox Church. The discontent among the Georgians resulted from the fact that in addition to the first exarch, the metropolitan Varlaam, bishops who were not Georgians were appointed to this position. 
and continued to be subject to the bishops appointed by Moscow ecclesiastical authorities. ${ }^{34}$ Mostowski claimed that central Soviet authorities, in implementing their plans to deprive the Georgian Orthodox Church of its autonomy, took very clever preparatory measures to facilitate the implementation of their intentions. To this end, almost immediately after the meeting in Kutaisi and electing a vice-Catholicos submissive towards the Bolshevik influence, Moscow ecclesiastical authorities ordered, in a special decree, the actual unity of the Orthodox Church in Georgia. Namely, by virtue of this document, the Orthodox Russians were included in the Georgian Orthodox Church and the Russian clergy were subordinated to the supreme authority of the Georgian Orthodox Church. In this way, the consul wrote, an element loyal to central Russian authorities was introduced to the Orthodox Church having all the features of a national church, just as it had happened in the old days, when subordination to the Russian Synod was established.

According to the Polish diplomat, the retaining of the autocephaly of the Georgian Orthodox Church and the title of Catholicos were highly undesirable for the central authorities in Moscow due to both their religious-denominational policy, as well as the overall internal policy of the Soviet Union. He justified his opinion by stating that the power of a Catholicos in the East was in fact greater than the power of the central Orthodox Church authorities in Moscow. In the case of retaining the title of Catholicos such a state could be maintained also in the future, which would not be convenient for the communists. Mostowski also noted here that although after the recent events the Georgian Orthodox Church was de facto subordinated to the authorities in Moscow, even the formal retention of the title of Catholicos was considered from the point of view of Soviet policy as something undesirable and dangerous.

The consul believed that based on the above mentioned information, the results of the council scheduled for June, during which a new Catholicos should be elected, seemed to be problematic. In his opinion, there should be no doubt as to the fact that the Georgian clergy loyal to the autocephaly, co-operating with the Georgian intelligentsia, would not give in easily and would lead a vigorous campaign in defence of the national Georgian Orthodox Church. At this point, the consul again referred to his sources, according to which persons under the influence of the central authorities in Moscow would not dare, as yet, to risk open confrontation, and would only seek to defer the election of a Catholicos. Only with time, when they have led to the strengthening if their position, would they openly take measures to eliminate the autocephaly.

According to Mostowski, such an uncertain attitude of the clergy remaining under the Bolshevik influence was conditioned to a large extent by the very hostile

34 Taking into account what Z. Mostowski claimed that the Russians in Georgia did not submit to the Catholicos, the earlier quoted data that the Georgian Orthodox Church comprised $90 \%$ of Georgia's population seem even more exaggerated. 
attitude of Georgian society (not only the Orthodox), towards the people responsible for the split in the Georgian Orthodox Church. In confirmation of this state of affairs, the diplomat cited the example of Vice-Catholicos Tsitskishvili who, facing common dislike for him, recognized his position in Tiflis as so uncertain that he left for Abkhazia. ${ }^{35}$ Next, Mostowski reported that the society's attitude to the clergy was very unfriendly. He justified it by providing accidentally acquired information according to which Tsitskishvili's repeated attempts to preach in different churches were successfully thwarted. In the Sioni Cathedral ${ }^{36}$ he was prevented from celebrating the Holy Mass - the necessary ecclesiastical robes and utensils were hidden from him. According to the consul, it could be assumed that in retaliation for such spontaneous symptoms of attachment of the population of Georgia to their national Orthodox Church, groups of Komsomol youth, with peculiar ferocity, organized in all churches in Tyflis during the Easter holidays scandals, dances, etc., perpetrating scandalous excesses, especially in relation to women.

At the end of the report, the Polish diplomat pointed out that the extremely important problem of the split in the Georgian Orthodox Church, just like all the important events associated with it, including the death of Catholicos Ambrosius, passed completely unnoticed on the pages of the local press. Mostowski reported that these issues were not discussed even in casual conversations among the local intelligentsia, at least in the presence of employees of the Polish consulate. He believed that it was probably due to the fear of the authorities "being very particular about the loyalty of citizens", as well as the prevailing opinion about the Poles as exceptionally dangerous people and, therefore, particularly well guarded by the Soviet secret service. Mostowski admitted that he was unable to change this opinion, first of all because according to him it was well grounded, at least in the sense that the Polish consulate staff were the most closely watched of all the representatives of foreign countries having their representatives in Tiflis. This situation continued despite the fact that Mostowski managed to establish a friendly relationship, not only an official but also informal-personal one, with Karklin, ${ }^{37}$ a representative of the People's Commissariat for Foreign Affairs, his deputy Bataitis, as well as with representatives of governmental spheres from other institutions. The consul noted that the observation carried out by the Soviet services was not abated, because the Polish consulate employees were considered a "dangerous" element in the territory of the post's activity, i.e. the territory of the Transcaucasian republics.

${ }^{35}$ It is worth noting that Ch. Tsitskishvili was also the metropolitan of the Abkhazian diocese.

36 Sioni is one of the most important Orthodox churches in Georgia. It is located in the centre of Tbilisi. Until the erection in 2004 of Tsminda Sameba, the Sioni Cathedral was the cathedral church of the Catholicos. The name of the church refers to Mount Zion in Jerusalem, and the temple was dedicated to the Dormition of the Holy Mother of God.

${ }^{37}$ It is about the Latvian, Otto Karklin. In the years 1924-1929, he was a representative of the People's Commissariat of Foreign Affairs at the Transcaucasian Socialist Federative Soviet Republic. O. Karklin was arrested in January 1938 and in October 1939 he was sentenced to 10 years in a labour camp; he died in 1942. 
The presented document proves that, in the 1920s, Polish diplomacy was interested in the processes taking place in the Georgian Orthodox Church. To a large extent, this was a consequence of perceiving the Soviet Union by Poland as the greatest threat to its security at the time. For this reason, Polish diplomats paid special attention to those factors that could potentially pose a barrier to the growth of influence of communist power in the individual union republics. The Georgian Orthodox Church was considered as one of such elements, i.e. one remaining in opposition to the central authorities in Moscow. However, it may be debatable whether Mostowski was really well acquainted with the situation in the Georgian Orthodox Church. Clearly, the consul wrote about the Georgian Orthodox Church as about a unity that only the communists wanted to destroy. The fact is that the most important clerics unanimously sought to restore its autocephaly. However, a ruthless war between them continued, which became visible already at the election of the first Catholicos in 1917. There were two candidates: Bishop Kyrion and Bishop Leonid. The former won by a small number of votes, but Bishop Leonid's camp did not accept the defeat. They began issuing a magazine openly in opposition to the Catholicos, which was unheard of in the Orthodox world. ${ }^{38}$ Less than a year after his election, in June 1918, Kyrion was assassinated. There are some indications that the murderer was associated with the supporters of Bishop Leonid, who became the new Catholicos. The Menshevik Georgian authorities quickly closed the investigation into Kyrion's death. Clearly, political decision-makers did not even attempt to investigate the murder. It can be assumed that the reason was the fear that the whole matter would weaken the position of the newly formed state in the international arena, should the intrigues within the national Orthodox Church be laid bare. After 1921, the new Bolshevik authorities did not resume the investigation, because there would be no advantage in that for them. The analysis of the report shows that Mostowski did not have any information on the circumstances of the death of Catholicos Kyrion. ${ }^{39}$

38 The magazine was called sbsmo boø y3s (in Polish "The New Word") and was issued in 1918.

39 After 1991 and the declaration of independence, the thesis that Kyrion had been assassinated by the Bolsheviks became popular in Georgia. However, there is no evidence, even indirect, that might indicate their participation in the conspiracy. The Bolsheviks gained nothing from the liquidation of Kyrion and replacing him in office by Catholicos Leonid. It was primarily Kyrion's Orthodox Church opponents that benefited from his death. The thesis that the assassination of the Catholicos was the result of internal conflicts in the Georgian Orthodox Church is also confirmed by the reaction of the Menshevik government. It sought to close the investigation as soon as possible and did not attempt to provide an explanation of this well-known assassination. It can be assumed that if the Bolsheviks had been involved in the murder, the government would have used this fact against them for propagandist reasons. By contrast, revealing that the whole thing stemmed from the conflict among the Georgian clergy would have adversely affected the image of the country, which only a month earlier declared its independence. 
It is noticeable that the Polish diplomat was particularly interested in the question of the conversion of Georgian bishops and intellectuals to Catholicism. Certainly, if such a phenomenon was common, it would correspond to the political interests of Poland. The Polish state, as the strongest centre of Catholicism in Central and Eastern Europe, sought an opportunity to increase its influence on the international arena, especially in the East, through the use of religious factors. What is noticeable here is an excessive emphasis which Mostowski laid on the conversion of Orthodox clergy to Catholicism. Eventually, none of the Georgian bishops decided to take such a step, and conversion among the intelligentsia was not a mass phenomenon, for it concerned only very few people. For this reason, conversion to Catholicism was a matter of sporadic cases and, consequently, could not lead to any serious political or social consequences. The Polish diplomat saw the primary reasons for the apostasy from the Orthodox Church in the infiltration of the Georgian Orthodox Church by the Soviet secret service, much to the dislike of a large part of the clergy. Until modern times, no detailed comparative studies on the influence of the Bolsheviks on the various religious groups in Georgia have been performed. The special significance that the communists attached to the subordination of the Orthodox Church of Georgia to them in the first period following the establishment of the Soviet power resulted from its significant impact on society. The Catholic Church in Georgia in the 1920s was a marginal force and was not in the centre of interest of the federal government, especially in the South Caucasus. It can be assumed, with high probability, that in the case of increased interest of the Georgian society in it, it would have been infiltrated to a similar extent as the Orthodox Church, and perhaps even more, mainly because of its hierarchical structure and location of its superior, the pope, outside the control of the Bolsheviks. As a result, the Catholic Church in the South Caucasus could have been subjected to even more repressive actions than the Orthodox Church, which the communists were able to completely subordinate to them, including its most important decision-makers.

Ultimately, Mostowski's predictions turned out to be off the mark and the communists neither liquidated the autocephaly of the Georgian Orthodox Church, nor abolished the title of the Catholicos. The council at which, following Ambrosius' death, the election of a new Catholicos was scheduled, was held in accordance with the earlier arrangements. In June 1927, Christophor III, who proved to be entirely dependent on the Bolsheviks, was elected the superior of the Orthodox Church. During his rule, the confrontation of the clergy with the Soviet authorities ended, as the communists completely subordinated the structure of the Georgian Orthodox Church to themselves. 


\section{The death of Catholicos Ambrosius and its impact on the fate of the Georgian Orthodox Church in Zygmunt Mostowski's opinion Abstract}

The article presents a report written by the Polish diplomat Zygmunt Mostowski on the death of Catholicos-Patriarch of All Georgia Ambrosius and its consequences for the future of the Georgian Orthodox Church. Ambrosius died in March 1927, when Mostowski was the head of the Polish consulate in Tbilisi (1926-1931). The report, prepared for the Polish Ministry of Foreign Affairs, is kept in the archives of the Polish Institute and Sikorski Museum in London. Mostowski focused mainly on the infiltration of the Georgian Orthodox Church by the Soviet special services; he warned against a possibility of conversion to Catholicism of several of the Georgian Church hierarchs (including few bishops), as well as of a large part of Georgian intellectuals. But the Polish diplomat's predictions did not come true and there were only some individual cases of conversion.

The presented document evidences the fact that in the 1920s the Polish diplomacy was interested in processes occurring within the Georgian Orthodox Church. In a large part it resulted from perceiving the Soviet Union as a major threat to the security of the Polish state. And for this reason Polish diplomats paid special attention to those factors that could block the increasing influence of the communist power in individual republics of the Soviet Union. And the Georgian Orthodox Church was regarded as one of such factors, opposing the central authorities in Moscow.

\section{Кончина католикоса Амвросия и ее влияние на судьбу Грузинской православной церкви согласно мнению Зыгмунта Мостовского Аннотация}

В статье был представлен отчет Зыгмунта Мостовского на тему кончины католикоса Амвросия и возможных последствий этого происшествия для Грузинской православной церкви. Мостовский в 1926-1931 гг. был начальником польского консульства в Тифлисе и кончина Амвросия, случившаяся в марте 1927 г., пришлась на период его работы в Грузии. Доклад дипломата, составленный для польского Министерства иностранных дел, хранится в архиве Польского института и Музея им. ген. Сикорского в Лондоне.

Мостовский сосредоточился, прежде всего, на инфильтрации советских спецслужб в Грузинскую православную церковь. Он также сделал сильный акцент на возможность перехода церковных сановников (включая нескольких епископов), как и большей части грузинской интеллигенции в католичество. Однако прогнозы польского дипломата не оправдались и случаи обращения были лишь единичными.

Представленный документ является доказательством того, что польская дипломатия в 20-х гг. XX в. была заинтересована в процессах, происходивих в лоне Грузинской православной церкви. В значительной степени это было результатом того, что в это время Польша воспринимала Советский Союз как самую большую угрозу своей безопасности. Из-за этого польские дипломаты обращали внимание на те факторы, которые потенциально могли представлять собой препятствие росту влияния коммунистической власти в отдельных союзных республиках. Одним из таких элементов, оппозиционно настроенных к центральным властям в Москве, считалась именно Грузинская православная церковь. 


\section{Bibliography (selection)}

\section{Source}

Mostowski, Z., "On the death of Catholicos Ambrosius and the split in the Georgian Orthodox Church", the archives of the Polish Institute and General Sikorski Institute, assembly: Embassy of the Republic of Poland in London, no A.12P, subassembly no. 11, file 3: "Soviet Russia - political and information reports from the Consulates in Leningrad, Minsk and Tiflis".

\section{Literature}

Kiknadze V., “Krótki zarys życia i działalności katolikosa-patriarchy Kiriona II”, in: Dokumenty klasztoru oo. kamedułów $z$ Pożajska w Państwowym Archiwum Historycznym w Tbilisi, ed.

I. Czamańska, Poznań, 2012.

Materski W., Gruzja, Warszawa, 2000.

Materski W., "Polsko-radziecka konwencja konsularna z 18 lipca 1924 roku”, Dzieje Najnowsze, 4 (1973).

Tchantouridze L., "Russian Annexes Georgia. Georgian Patriarch's Letter to the 1922 Genoa Conference", The Canadian Journal of Orthodox Christianity, 3 (2008), no. 3.

Всесоюзная перепись населения 1926 года, http://demoscope.ru/weekly/ssp/ussr_nac_26. php?reg=5 (access: 6 January 2016).

Святой исповедник Амвросий (Хелая) перед коммунистическим правосудием. Сборник составила, предисловием и комментариями снабдила Динара Дарсалия, Тбилиси, n.d.

Топтыгин А., Неизвестный Берия, Москва, 2002.

Przemysław Adamczewski (b. 1981), specialist in Caucasus studies; graduated with an MA degree in international relations from Adam Mickiewicz University in Poznań; received the doctoral degree in 2010 for his dissertation concerning the Karabakh issue in Azerbaijan's policy after 1991 (it won a prize in the Robert Mrozewicz Competition for the Best Doctoral Thesis in International Relations and Diplomacy in 2011, organised by Collegium Civitas in Warsaw); in 2013-2015 worked in Ivane Javakhishvili Institute of History and Ethnology in Tbilisi and pursued the research project 'The mythologisation of historical memory as a factor of ethnic conflicts in the Caucasus'; employed in the Institute of Political Studies of the Polish Academy of Sciences since 2016 (adprzem@op.pl). 